Article

\title{
Some Properties of Densified Eastern Redcedar as Function of Heat and Pressure
}

\author{
Onur Ulker ${ }^{1, *}$ and Salim Hiziroglu ${ }^{2}$ \\ 1 Department of Interior Architecture and Environmental Design, University of Kırıkkale, Yahşihan 71450, Turkey \\ 2 Department of Natural Resource Ecology and Management, Oklahoma State University, \\ Stillwater, OK 74078-6013, USA; salim.hiziroglu@okstate.edu \\ * Correspondence: ulker79o@hotmail.com or onurulker@kku.edu.tr; Tel.: +1-405-385-1562
}

Received: 31 August 2017; Accepted: 24 October 2017; Published: 7 November 2017

\begin{abstract}
The objective of this study was to evaluate some of the properties of densified eastern redcedar as function of temperature and pressure. Surface quality, adhesive bondline shear strength, hardness, and color changes of the samples compressed using different temperature levels ranging from $100{ }^{\circ} \mathrm{C}$ to $180^{\circ} \mathrm{C}$ were investigated. Based on the findings in this work, surface roughness of compressed specimens decreased with increased temperature. Overall adhesive bondline shear strength of the samples decreased as compared to that of control specimens as a result of compression. It appears that densified samples exposed to a temperature of $180^{\circ} \mathrm{C}$ had significantly darker surface than those of the others, based on color measurement. Data found in this work provide some basic information for more efficient use of underutilized species such as eastern redcedar.
\end{abstract}

Keywords: eastern redcedar; compression; heat treatment; roughness; hardness; color change

\section{Introduction}

Densification of wood has been used for many years for different applications [1,2]. The typical densification process of wood is defined as compression by pressing with a combination of heat treatment or filling the cells with the application of different materials, including polymer or natural resins [3-6]. When heat treatment is combined with compression, certain properties of the wood such as surface roughness, color modification, and dimensional stability can be enhanced. One of the most important advantages of wood densification is to improve major mechanical properties of the member, and this approach plays a more important role in the case of the densification of low-density species. The thermomechanical compression and densification of wood generally take place in four distinctive stages. These are softening, plastic softening, and plasticizing of the cell wall compression in a radial grain orientation, climatizing in a densified unit, and fixation of dimensional stability [5,7-9].

Species, temperature level, softening time span, pressure, and densification method are major parameters influencing the final properties of densified material [10]. In a previous study, the surface roughness of compressed birch and alder veneer samples was evaluated [11]. It was found that overall surface quality of the densified samples increased with compression level [11]. Surface quality of thermally compressed Douglas fir veneer samples was also investigated in a past study [12]. Based on roughness measurements carried out using a stylus-type equipment, specimens compressed with higher pressure and temperature had smoother surface than those exposed to lower pressure and temperature levels.

Aydin and Colakoglu evaluated the influence of veneer drying temperature on surface roughness of plywood panels, and it was concluded that samples from alder and spruce species had enhanced surface quality with increasing temperature [13]. It was also evaluated of bonding strength of heat treated and compressed Eastern redcedar and it was found that combination of heat treatment and compression enhanced overall surface quality of the samples in the form of their roughness determined 
using a stylus type equipment [14]. Hydrothermal treatment of wood samples in a closed chamber was employed in a past study [1]. In this approach, the wood specimens were compressed by employing a heated setup in one step before they were cooled off. This idea is relatively related to the Staypak method [15]. Surface densification of maple specimens was also carried out using heat and compression in a continuous belt type press by heating up the surface of the sample to a temperature of $220^{\circ} \mathrm{C}$ [16].

Eastern redcedar (Juniperus virginiana L.) is one of the widely distributed species in Oklahoma. The current area covered by eastern redcedar in Oklahoma is estimated to be beyond 4.5 million hectares, and it was projected to be 6.3 million ha by 2013 [17]. The cedar population is growing at the rate of 380 hectares per day, resulting in a significant adverse impact on ecology. The cost of problem caused by eastern redcedar invasion was approximately $\$ 447$ million in 2013 [17]. Although properties of eastern redcedar have been comprehensively investigated and evaluated, there is very little or no information on surface properties, hardness, and color changes of such species as function of thermal compression process. Therefore, the objective of this study was to determine such properties of eastern redcedar samples compressed in a hot press. Data from this work could be beneficial for more efficient utilization of this under-utilized species for value-added products with enhanced properties.

\section{Materials and Methods}

\subsection{Preparation of Samples and Applied Tests}

Defect-free eastern redcedar (Juniperus virginiana L.) strips with dimension of $5 \mathrm{~cm}$ by $4 \mathrm{~cm}$ by $2 \mathrm{~cm}$ were supplied by a local sawmill in Oklahoma, USA. After this they were kept in a conditioned chamber with a temperature of $20^{\circ} \mathrm{C}$ and relative humidity of $65 \%$ until they reached equilibrium moisture content of $12 \%$. A total of 175 samples with $2.5 \mathrm{~m}$ length were cut from long strips with tangential grain orientation, as illustrated in Figure 1.

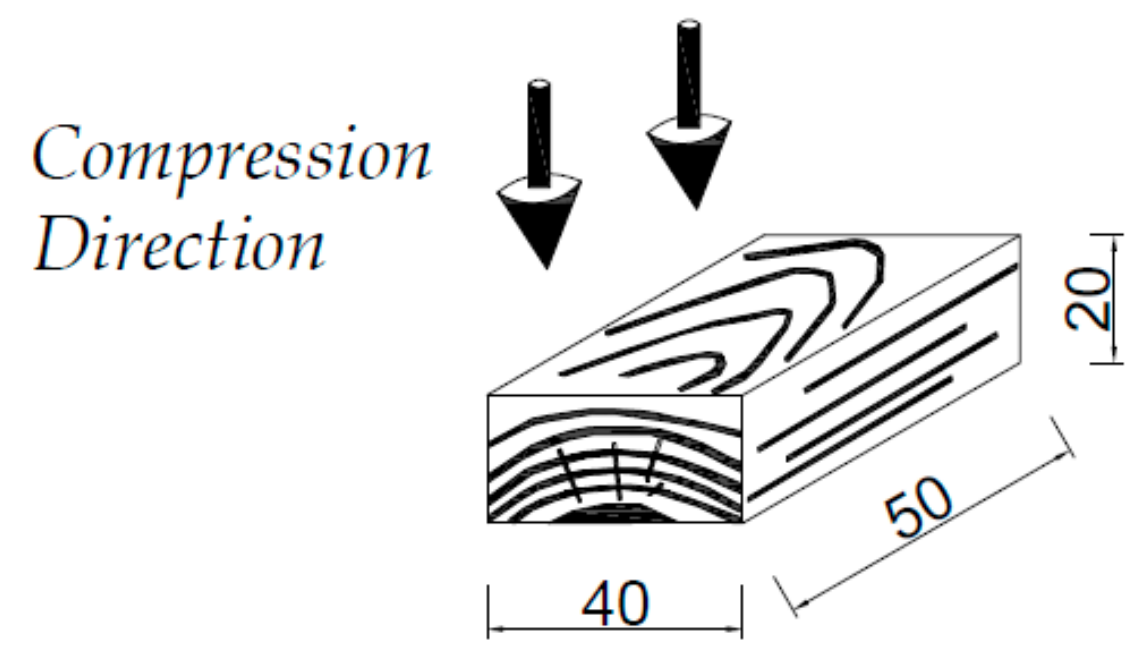

Figure 1. Compression direction and sample size $(\mathrm{mm})$ before densification.

Tangential surfaces of each sample were sanded sequentially with 100 and 200 grit sand paper with several light strokes. A total of 125 samples-25 for each temperature level $\left(100{ }^{\circ} \mathrm{C}, 120^{\circ} \mathrm{C}, 150^{\circ} \mathrm{C}\right.$, $180^{\circ} \mathrm{C}$ ) and control sample-were compressed on their tangential surface on a Carver press with a capacity of 10 ton. Samples were compressed using a pressure of $6.08 \mathrm{MPa}$ at each temperature level for $20 \mathrm{~min}$. Both control and compressed samples were kept in the conditioning room for several days prior to any tests. Table 1 displays sample size and testing schedule. 
Table 1. Dimensions of the samples densified using heat and pressure.

\begin{tabular}{|c|c|c|c|c|}
\hline \multirow{2}{*}{ Applied Tests } & \multirow{2}{*}{$\begin{array}{l}\text { Size of Specimens Before } \\
\text { Densification }(\mathrm{mm})\end{array}$} & \multirow{2}{*}{$\begin{array}{l}\text { Size of Specimens After } \\
\text { Densification (mm) }\end{array}$} & \multicolumn{2}{|c|}{ Number of Specimens } \\
\hline & & & Control & Densified \\
\hline Density & $50 \times 40 \times 20$ & $50 \times 40 \times 14$ & 5 & 20 \\
\hline Sheer Strength & $90 \times 40 \times 20$ & $90 \times 40 \times 14$ & 5 & 20 \\
\hline $\begin{array}{l}\text { Surface Roughness } \\
\text { Parallel to the Grain }\end{array}$ & $50 \times 40 \times 20$ & $50 \times 40 \times 14$ & 5 & 20 \\
\hline $\begin{array}{l}\text { Surface Roughness } \\
\text { Perpendicular to the Grain }\end{array}$ & $50 \times 40 \times 20$ & $50 \times 40 \times 14$ & 5 & 20 \\
\hline $\begin{array}{c}\text { Janka Hardness Strength } \\
\text { Radial D. }\end{array}$ & $50 \times 40 \times 20$ & $50 \times 40 \times 14$ & 5 & 20 \\
\hline $\begin{array}{c}\text { Janka Hardness Strength } \\
\text { Tangential D. }\end{array}$ & $50 \times 40 \times 20$ & $50 \times 40 \times 14$ & 5 & 20 \\
\hline Color Differences & $50 \times 40 \times 20$ & $50 \times 40 \times 14$ & 5 & 20 \\
\hline
\end{tabular}

\subsection{Moisture Content and Density of the Samples}

Moisture content of the control samples was determined by measuring their initial and oven-dried weight at an accuracy of $0.01 \mathrm{~g}$ after they were kept in an oven at a temperature of $103 \pm 2{ }^{\circ} \mathrm{C}$. The following equation was employed for moisture content calculation of the samples. Samples were taken from the oven and kept in a dry chamber. Moisture content was calculated with this formula:

Moisture Content $(\%)=[($ Mass When Cut - Oven Dry Mass $) /$ Oven Dry Mass $] \times 100 \%$

Density of each samples was also determined by weighting and measuring dimensions at accuracy levels of $0.01 \mathrm{~g}$ and $0.1 \mathrm{~cm}$, respectively.

\subsection{Densification Process}

Samples were cut from the strips to the dimensions of $50 \mathrm{~mm}$ by $40 \mathrm{~mm}$ by $20 \mathrm{~mm}$ (length $\times$ width $\times$ thickness). In the next step, the samples were stacked and left to dry naturally according to standards. They were kept in a climate chamber at a temperature of $20 \pm 2{ }^{\circ} \mathrm{C}$ and a relative humidity of $65 \pm 5 \%$ until they reached constant weight.

The press temperature was adjusted to the target temperature levels at an accuracy of $\pm 1^{\circ} \mathrm{C}$. The samples were placed on the lower platen in such a way that the pressure would be applied in a radial direction. In order to ensure heat transfer to both sides, the upper flat surface was contacted on surfaces without applying pressure. The samples were kept until they reached the target temperature values of $100{ }^{\circ} \mathrm{C} 120^{\circ} \mathrm{C}, 150{ }^{\circ} \mathrm{C}$, and $180^{\circ} \mathrm{C}$.

The pressure gauge of the press was adjusted to provide a densification pressure of $6.08 \mathrm{MPa}$. The samples were densified by being compressed manually with a $20 \mathrm{~m} / \mathrm{min}$ loading speed, as shown in Figure 2. Samples were pressed at constant pressure to eliminate possible spring-back effect, as illustrated in Figure 3. In the next step, samples were removed from the press and kept in room condition for 7 days. 


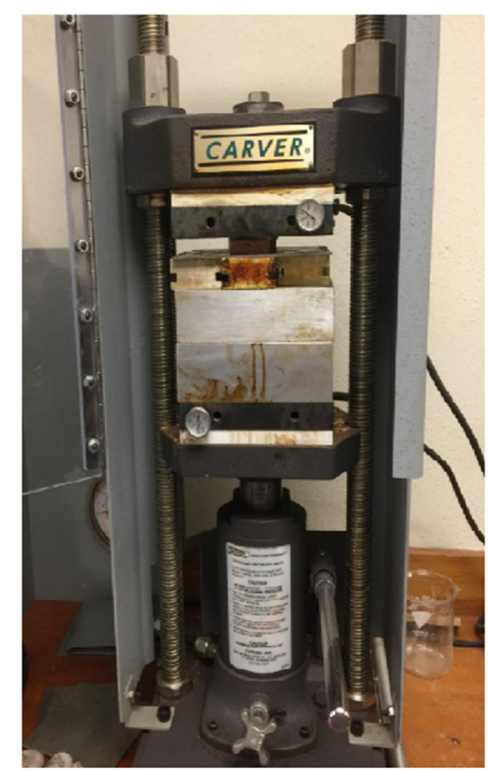

Densification with Carver Press

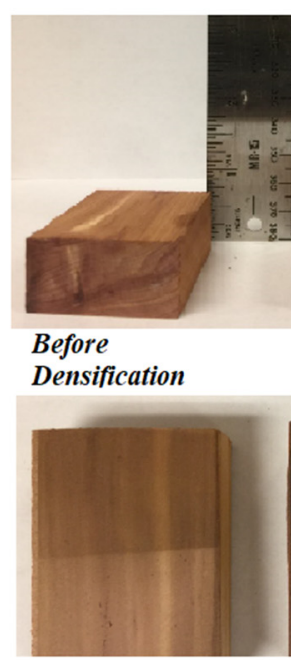

Densified

at $100^{\circ} \mathrm{C}$

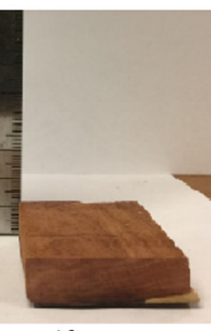

After

Densification

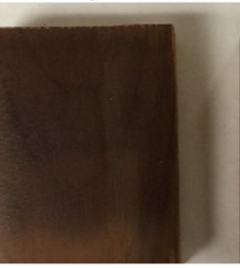

Densified at $120^{\circ} \mathrm{C}$

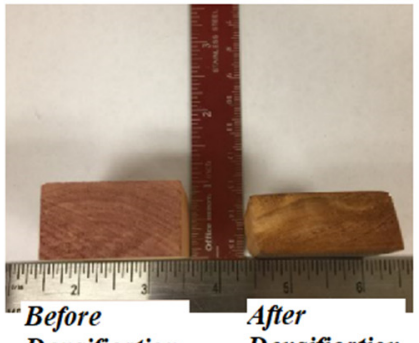

Densification Densification

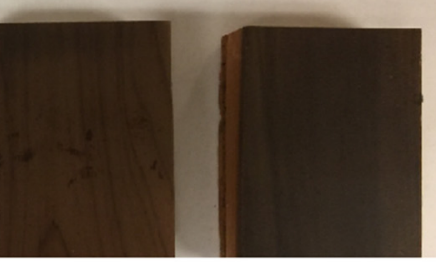

Densified at $150^{\circ} \mathrm{C}$
Densified at $180^{\circ} \mathrm{C}$

Figure 2. Densification process with Carver laboratory press and samples after densification.

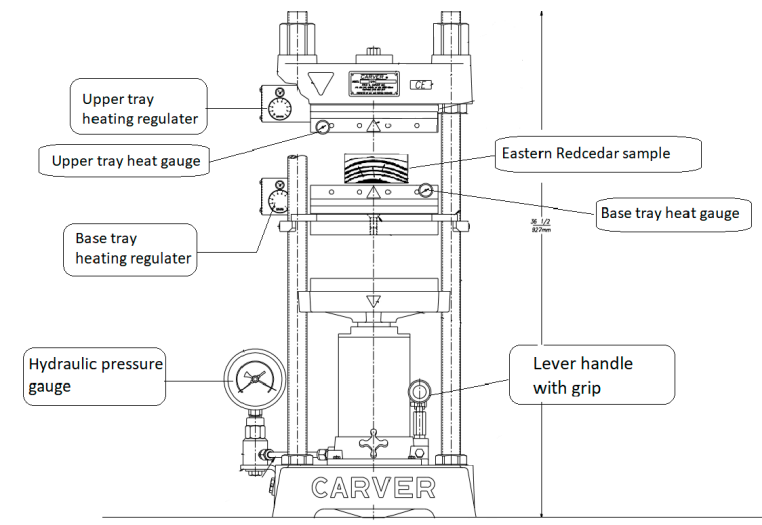

Before Densification Process

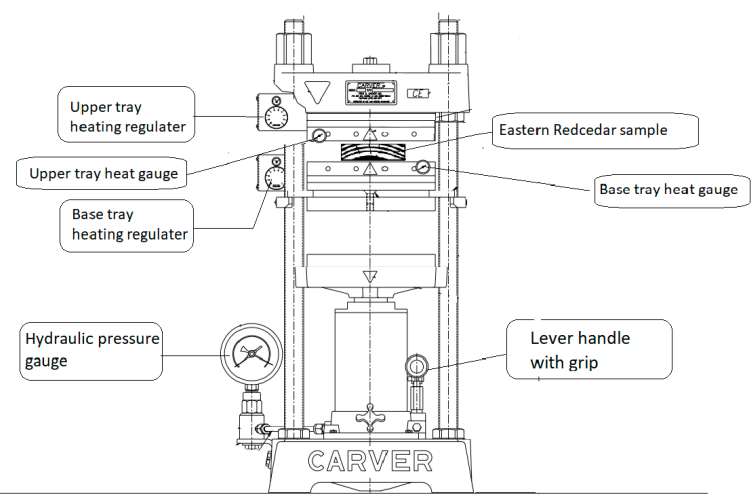

After Densification Process

Figure 3. Densification process of the samples in Carver laboratory press.

\subsection{Surface Roughness Measurement}

A stylus type T-500 Hommel America portable profilometer (Hommel Inc., Detroit, MI, USA) was employed for surface roughness measurement. Six measurements with a tracing span of $15.2 \mathrm{~mm}$ were taken from both sides of the samples across and along the grain orientation by employing a Hommel T-500 profilometer before and after heat treatment and compression of the samples. The stylus unit used in this study consists of the main unit and the pickup model TkE. The pickup has a skid type diamond stylus with $5 \mu \mathrm{m}$ tip radius and a 90-tip angle. The stylus traverses the surface at constant speed of $1 \mathrm{~mm} / \mathrm{s}$ over $15.2 \mathrm{~mm}$ tracing length, converting the vertical displacement of the stylus into an electrical signal [18]. The calibration of the instrument was checked every 100 measurements by using a standard reference plate with Ra values of $3.02 \mu \mathrm{m}$ and $0.48 \mu \mathrm{m}$. A cut-off length of $2.54 \mathrm{~mm}-\mathrm{a}$ parameter that differentiates roughness and waviness profiles from each other-was used for the test as illustrated in Figure 4 [18]. 
Surface Roughness Along the Grain Orientation

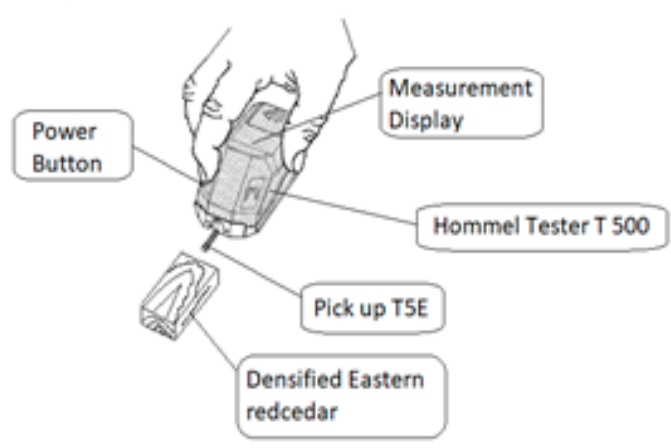

Surface Roughness Across the Grain Orientation

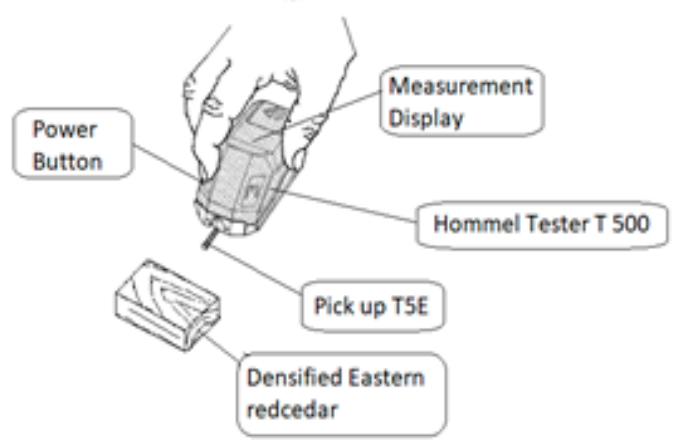

Figure 4. Surface roughness measurement test.

\subsection{Hardness Measurement of the Samples}

Hardness of the control and treated specimens was tested by embedding a hemisphere steel having $11.2 \mathrm{~mm}$ diameter onto their tangential surface to the grain directions using a Comten 95 Series Universal Testing machine (Com-Ten Industries, Pinellas Park, FL, USA). Four measurements were taken from each sample and recorded in lbs to evaluate their Janka hardness, as illustrated in Figure 5 [19].

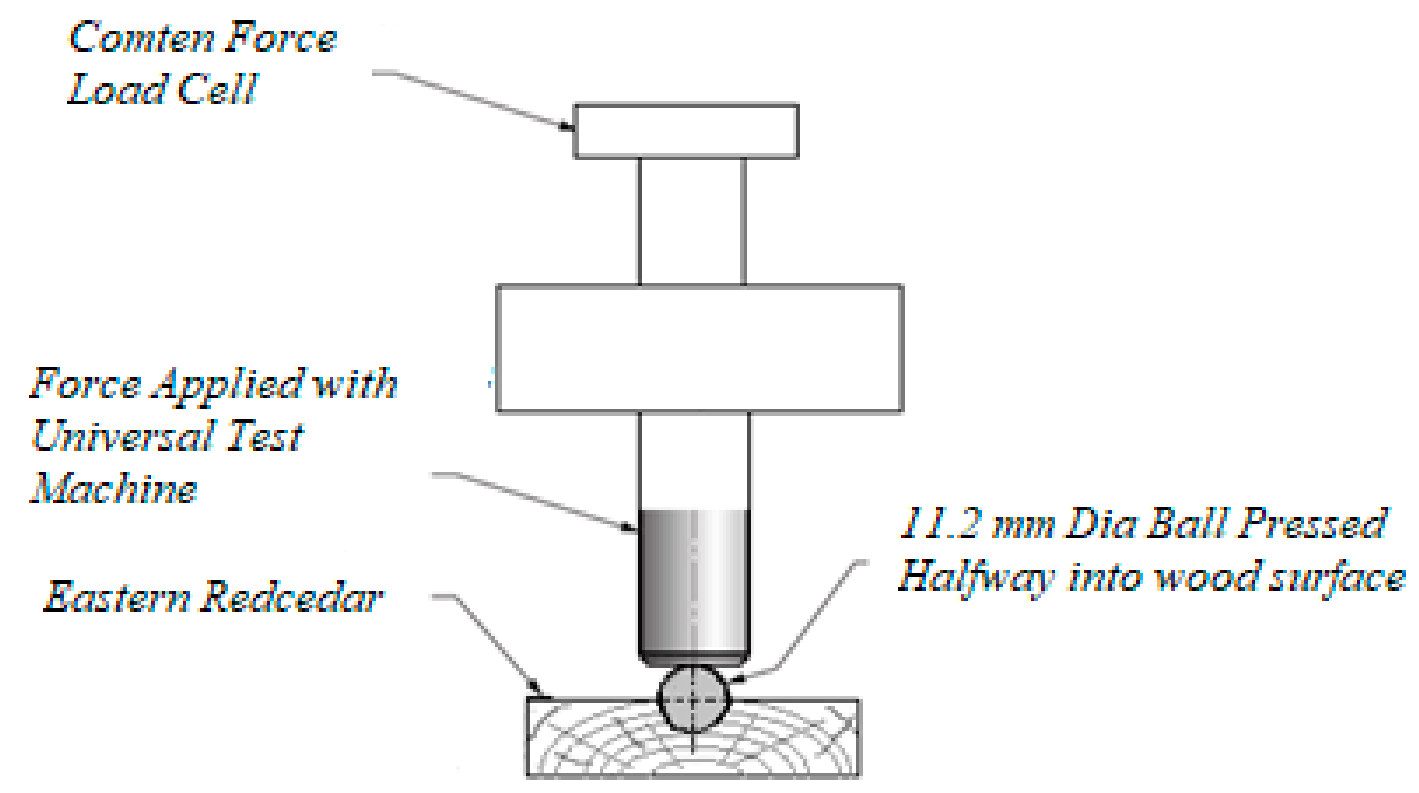

Figure 5. Janka hardness measurement with Comten 95 Series Universal Testing machine.

\subsection{Adhesive Bondline Shear Strength Process}

Polyvinyl acetate (PVAc) adhesive was used to bond samples in the form of pair to determine their adhesive bondline shear strength. Adhesive was applied to both surfaces of each bondline shear pair at a spread rate of $120 \mathrm{~g} / \mathrm{m}^{2}$. The pair was then cold pressed using an approximate pressure of $40.8 \mathrm{~kg} / \mathrm{cm}^{2}$ for $20 \mathrm{~min}$ at room temperature before bondline shear tests were carried out. Adhesive bondline shear strength test was also carried out on a Comten testing unit (Com-Ten Industries, Pinellas Park, FL, USA) equipped with a load cell having capacity of $1000 \mathrm{~kg}$, as illustrated in Figure 6 [17]. 


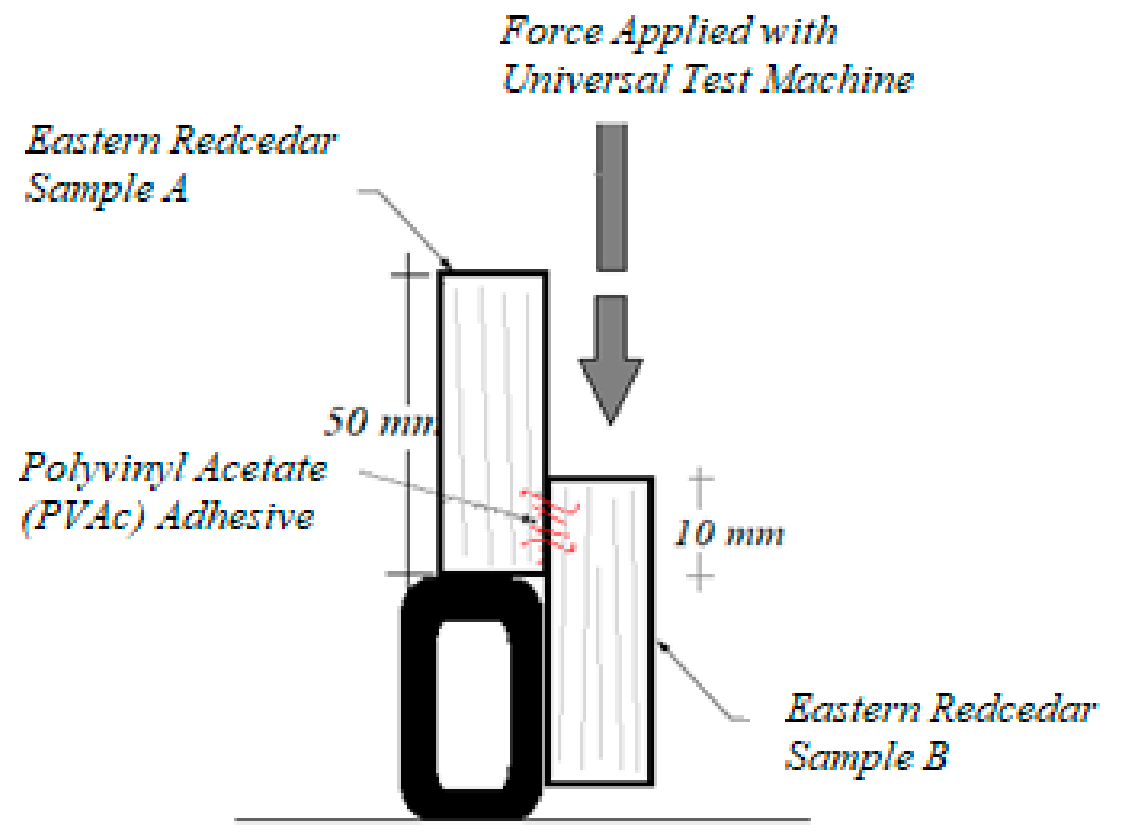

Figure 6. Adhesive bondline shear strength measurement with Comten 95 Series Universal Testing machine.

\subsection{Color Measurement of the Samples}

The color measurement of all specimens was recorded on the surface of specimens before and after heat treatment with a colorimeter FRU WR-10QC (Shenzhen Wave Optoelectronics Technology Co Ltd, Shenzhen, China). The sensor head was $8 \mathrm{~mm}$ in diameter. Measurements were carried out using a D65 illuminant and 10 degree standard observer (Shenzhen Wave Optoelectronics Technology Co Ltd., Shenzhen, China). Percentage of reflectance, collected at $10 \mathrm{~nm}$ intervals over the visible spectrum ranging from 400 to $700 \mathrm{~nm}$, was converted into the CIELAB color system (Shenzhen Wave Optoelectronics Co Ltd., Shenzhen, China), where $L^{*}$ describes the lightness, and $a^{*}$ and $b^{*}$ describe the chromatic coordinates on the green-red and blue-yellow axes, respectively.

From the $\mathrm{L}^{*}, \mathrm{a}^{*}, \mathrm{~b}^{*}$ values, the difference in the lightness $\left(\Delta \mathrm{L}^{*}\right)$ and chroma coordinates $\left(\Delta \mathrm{a}^{*}\right.$ and $\left.\Delta \mathrm{b}^{*}\right)$, hue angle $(\mathrm{h})$, saturation $\left(\mathrm{C}^{*}\right)$, and total color difference $(\Delta \mathrm{E})$ were calculated using the following formula.

$$
\begin{aligned}
\Delta \mathrm{L}^{*} & =L^{*}{ }_{t}-L^{*}{ }_{c} \\
\Delta \mathrm{a}^{*} & =a^{*}{ }_{t}-a^{*}{ }_{c} \\
\Delta \mathrm{b}^{*} & =b^{*}{ }_{t}-b^{*}{ }_{c}
\end{aligned}
$$$$
\mathrm{h}=\operatorname{arctg}\left(\mathrm{b}^{*} / \mathrm{a}^{*}\right)
$$$$
\mathrm{C}^{*}=\left(\mathrm{a}^{* 2}+\mathrm{b}^{* 2}\right)^{1 / 2}
$$$$
\Delta \mathrm{E}=\left(\Delta \mathrm{L}^{* 2}+\Delta \mathrm{a}^{* 2}+\Delta \mathrm{b}^{* 2}\right)
$$

where, $L^{*}, a^{*}, b^{*}$ are $L^{*}, a^{*}$, and $b^{*}$ of the heated specimens; $L^{*}, a^{*}{ }_{c}, b^{*}{ }_{c}$ are $L^{*}, a^{*}$, and $b^{*}$ of the control specimens, respectively.

On the hue circle, $h=0^{\circ}$ denotes redness and $h=90^{\circ}$ denotes yellowness, as illustrated in Figure 7 . Saturation $C^{*}$, corresponding to the distance between the color and the center of the chromaticity plane, is a measure of color intensity. The measurements of color were determined according to DIN 5033. The measurements are average values with standard deviations [20]. 


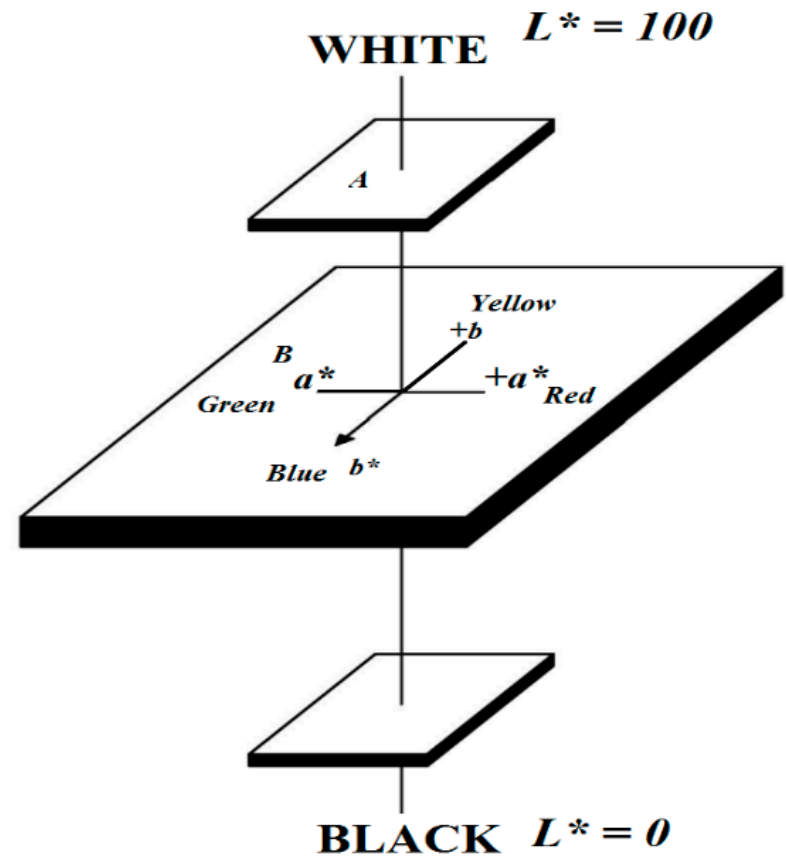

Figure 7. Color space defined by the $\mathrm{L}^{*}, \mathrm{a}^{*}, \mathrm{~b}^{*}$ axes. In addition, the deduced color parameter hue angle $\mathrm{h}$ is indicated (A: Color of occupation; B: Color of specimens; $\mathrm{A}^{\prime}$ : Color of occupation at equal lighting as color of specimens).

\subsection{Data Analysis}

One-way analysis of variance (one-way ANOVA) was performed to analyze the significant differences of all parameters used in this study. All results were computed using IBM Statistical Package for the Social Sciences (SPSS) software (IBM Inc., Armonk, NY, USA).

\section{Results and Discussion}

Table 2 displays test results of the specimens. The average density of the control samples was $0.46 \mathrm{~g} / \mathrm{cm}^{3}$. Overall density levels of the samples increased substantially with increasing press temperature. The increase was the highest in the case of the specimens having density of $0.93 \mathrm{~g} / \mathrm{cm}^{3}$ compressed at a temperature of $180{ }^{\circ} \mathrm{C}$. The moisture contents for the densified samples were $6-8 \%$.

Table 2. Average physical and mechanical properties of densified eastern redcedar at a pressure of 6.08 $\mathrm{MPa}$ and different temperature levels.

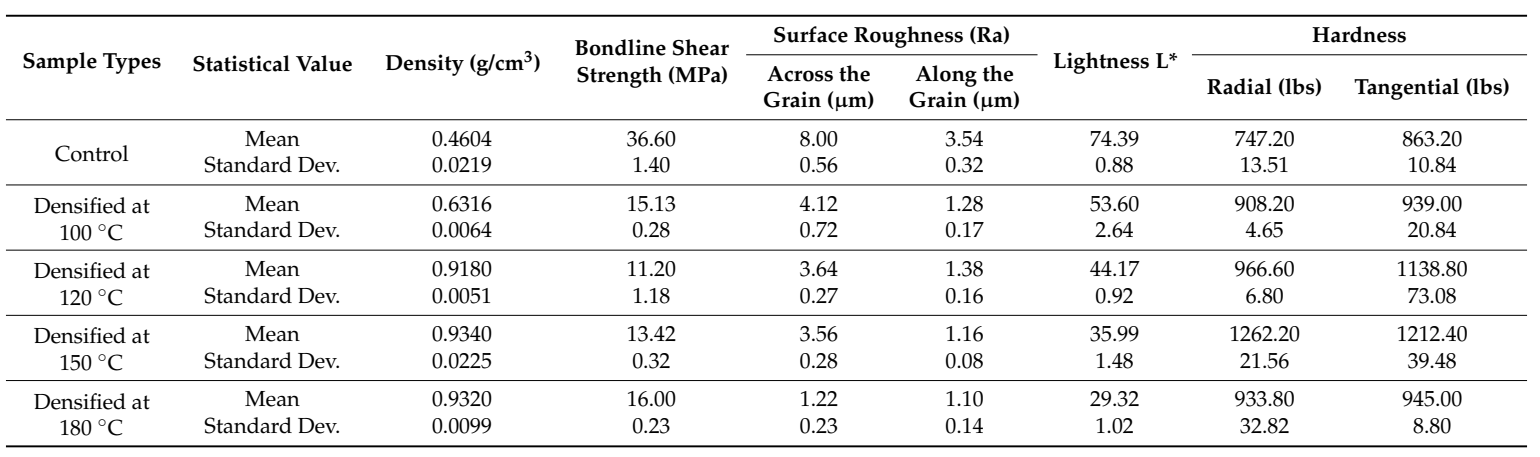

\subsection{Effect of the Temperature Level on Mechanical and Physical Properties}

The analysis of variance related to the effectiveness of the temperature level on densification enhanced overall mechanical properties of the samples, as displayed in Table 3. 
Table 3. Analysis of variance related to the effect of the temperature level on density.

\begin{tabular}{|c|c|c|c|}
\hline Applied Tests & Statistical Values & Sum of Squares & Level of Significance $(p \leq 0.05)$ \\
\hline Density & $\begin{array}{c}\text { Between Groups } \\
\text { Within Groups } \\
\text { Total }\end{array}$ & $\begin{array}{c}95,1473.36 \\
4638.80 \\
96,112.16\end{array}$ & 0.000 \\
\hline Adhesive Bondline Shear Strength & $\begin{array}{c}\text { Between Groups } \\
\text { Within Groups } \\
\text { Total }\end{array}$ & $\begin{array}{l}2121.47 \\
14.53 \\
2136.01\end{array}$ & 0.000 \\
\hline Surface Roughness Across to Grain & $\begin{array}{c}\text { Between Groups } \\
\text { Within Groups } \\
\text { Total } \\
\end{array}$ & $\begin{array}{c}120.03 \\
4.24 \\
124.27 \\
\end{array}$ & 0.001 \\
\hline Surface Roughness Along to Grain & $\begin{array}{c}\text { Between Groups } \\
\text { Within Groups } \\
\text { Total }\end{array}$ & $\begin{array}{c}21.57 \\
0.76 \\
22.33\end{array}$ & 0.000 \\
\hline Lightness & $\begin{array}{c}\text { Between Groups } \\
\text { Within Groups } \\
\text { Total }\end{array}$ & $\begin{array}{c}6172.75 \\
47.47 \\
6220.23\end{array}$ & 0.000 \\
\hline Hardness in Radial Direction & $\begin{array}{c}\text { Between Groups } \\
\text { Within Groups } \\
\text { Total }\end{array}$ & $\begin{array}{c}561,002.96 \\
11,546.80 \\
572,549.76\end{array}$ & 0.000 \\
\hline Hardness in Tangential Direction & $\begin{array}{c}\text { Between Groups } \\
\text { Within Groups } \\
\text { Total }\end{array}$ & $\begin{array}{c}545,846.64 \\
13,890.40 \\
559,737.04\end{array}$ & 0.001 \\
\hline
\end{tabular}

The densification process was found to be effective on the density, adhesive bondline shear strength, surface roughness perpendicular and parallel to grain orientation, lightness, hardness in radial and tangential directions of eastern redcedar specimens $(p<0.05)$. Table 4 displays the homogeneity test results related to the temperature levels that created a difference according to the values determined in this work.

In this study, five groups of heat treatment $100{ }^{\circ} \mathrm{C}, 120^{\circ} \mathrm{C}, 150{ }^{\circ} \mathrm{C}, 180^{\circ} \mathrm{C}$, and control groups were used to evaluate the of effect of temperature on physical and mechanical properties of the samples. All properties of the samples considered in this study were significantly changed compared with those of the control groups $(p<0.05)$ as a result of heat treatment. By comparing the density of heat treatment groups with control group, a significant increase was observed at temperature levels $100{ }^{\circ} \mathrm{C}$, $120^{\circ} \mathrm{C}, 150{ }^{\circ} \mathrm{C}, 180^{\circ} \mathrm{C}$, however a remarkable similarity was found between the heat treatment groups after exposure to a temperature of $120^{\circ} \mathrm{C}$. A substantial decrease in all specimen properties was also observed in all heat treatment groups. Color changes of the samples significantly decreased for those exposed to $100^{\circ} \mathrm{C}(p<0.05)$, while the overall values of hardness in radial and tangential directions after heat treatment significantly increased for the group exposed to a temperature of $100{ }^{\circ} \mathrm{C}$. On the other hand, hardness in radial and tangential directions started to decrease with exposure to temperature groups $150^{\circ} \mathrm{C}$ and $120^{\circ} \mathrm{C}$. Table 4 displays comparative test results.

Table 4. Comparative test results for the effect of densification on various properties of the samples at different temperatures for homogeneity groups.

\begin{tabular}{|c|c|c|c|c|c|c|}
\hline Physical and Mechanical Tests & $\begin{array}{c}\text { Densification } \\
\text { Temperature }\left({ }^{\circ} \mathrm{C}\right)\end{array}$ & H.G. ${ }^{*} \mathrm{~A}$ & H.G. ${ }^{*} B$ & H.G. ${ }^{*} \mathrm{C}$ & H.G. ${ }^{*} \mathrm{D}$ & H.G. ${ }^{*} \mathrm{E}$ \\
\hline \multirow{5}{*}{ Density } & Control Group & & & 0.460 & & \\
\hline & $100^{\circ} \mathrm{C}$ & & 0.631 & & & \\
\hline & $120^{\circ} \mathrm{C}$ & 0.918 & & & & \\
\hline & $150^{\circ} \mathrm{C}$ & 0.934 & & & & \\
\hline & $180^{\circ} \mathrm{C}$ & 0.932 & & & & \\
\hline \multirow{5}{*}{ Bondline Shear Strength } & Control Group & 36.60 & & & \multirow{5}{*}{11.20} & \\
\hline & $100^{\circ} \mathrm{C}$ & & 15.13 & & & \\
\hline & $120^{\circ} \mathrm{C}$ & & & \multirow{3}{*}{13.42} & & \\
\hline & $150^{\circ} \mathrm{C}$ & & & & & \\
\hline & $180^{\circ} \mathrm{C}$ & & 16.00 & & & \\
\hline
\end{tabular}


Table 4. Cont.

\begin{tabular}{|c|c|c|c|c|c|c|}
\hline Physical and Mechanical Tests & $\begin{array}{c}\text { Densification } \\
\text { Temperature }\left({ }^{\circ} \mathrm{C}\right)\end{array}$ & H.G. ${ }^{*} \mathrm{~A}$ & H.G. * B & H.G. ${ }^{*} \mathrm{C}$ & H.G. * D & H.G. ${ }^{*} \mathrm{E}$ \\
\hline \multirow{5}{*}{$\begin{array}{l}\text { Surface Roughness Across the } \\
\text { Grain Orientation }\end{array}$} & Control Group & 8.00 & & \multirow[b]{5}{*}{1.22} & & \\
\hline & $100^{\circ} \mathrm{C}$ & & 4.12 & & & \\
\hline & $120^{\circ} \mathrm{C}$ & & 3.64 & & & \\
\hline & $150^{\circ} \mathrm{C}$ & & 3.56 & & & \\
\hline & $180^{\circ} \mathrm{C}$ & & & & & \\
\hline \multirow{5}{*}{$\begin{array}{l}\text { Surface-Roughness Along the } \\
\text { Grain Orientation }\end{array}$} & Control Group & 3.54 & & & & \\
\hline & $100^{\circ} \mathrm{C}$ & & 1.28 & & & \\
\hline & $120^{\circ} \mathrm{C}$ & & 1.16 & & & \\
\hline & $150^{\circ} \mathrm{C}$ & & 1.38 & & & \\
\hline & $180^{\circ} \mathrm{C}$ & & 1.10 & & & \\
\hline \multirow{5}{*}{ Lightness } & Control Group & 73.39 & \multirow{5}{*}{53.60} & \multirow{5}{*}{44.17} & & \\
\hline & $100^{\circ} \mathrm{C}$ & & & & & \\
\hline & $120^{\circ} \mathrm{C}$ & & & & & \\
\hline & $150^{\circ} \mathrm{C}$ & & & & 35.99 & \\
\hline & $180^{\circ} \mathrm{C}$ & & & & & 29.32 \\
\hline \multirow{5}{*}{ Hardness in Radial Direction } & Control Group & & \multirow{5}{*}{966.60} & & 747.20 & \\
\hline & $100^{\circ} \mathrm{C}$ & & & 908.20 & & \\
\hline & $120^{\circ} \mathrm{C}$ & & & & & \\
\hline & $150^{\circ} \mathrm{C}$ & 1212.40 & & & & \\
\hline & $180^{\circ} \mathrm{C}$ & & & 933.80 & & \\
\hline \multirow{5}{*}{ Hardness in Tangential Direction } & Control Group & & \multirow{5}{*}{1139.20} & & 863.20 & \\
\hline & $100^{\circ} \mathrm{C}$ & & & 939.00 & & \\
\hline & $120^{\circ} \mathrm{C}$ & & & & & \\
\hline & $150^{\circ} \mathrm{C}$ & 1262.20 & & & & \\
\hline & $180^{\circ} \mathrm{C}$ & & & 945.00 & & \\
\hline
\end{tabular}

\subsubsection{Evaluation of Density}

Since the samples reached a certain threshold point of densification, no significant difference in their density values was observed when they were compressed at temperature levels of $120{ }^{\circ} \mathrm{C}, 150{ }^{\circ} \mathrm{C}$, and $180{ }^{\circ} \mathrm{C}$. However, statistical analysis resulted in significant difference for the values between control samples and those compressed at a temperature of $100{ }^{\circ} \mathrm{C}$ and the others, as illustrated in Figure 8.

After the densification process, the density of the specimens increased from $0.46 \mathrm{~g} / \mathrm{cm}^{3}$ to $0.93 \mathrm{~g} / \mathrm{cm}^{3}$ at all temperature levels, resulting in a $101 \%$ density increase. The control specimens and densified specimens appeared in separate homogeneity groups.

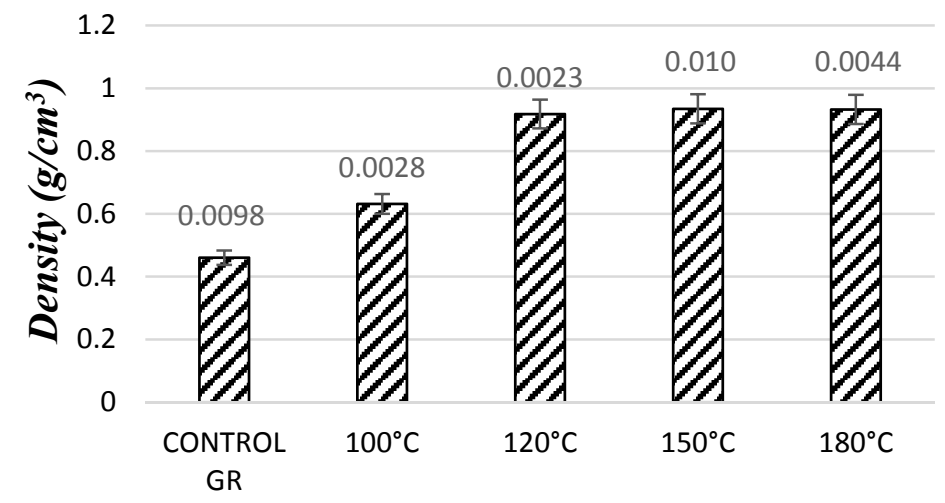

Heat Treatment Groups

Figure 8. Density values of the samples after the densification process. 


\subsubsection{Evaluation of Adhesive Bondline Shear Strength Test}

The control sample had an average adhesive bondline shear strength of $36.60 \mathrm{MPa}$, which was the highest value of the samples. Once samples were compressed under the influence of temperature levels of $100{ }^{\circ} \mathrm{C} 120^{\circ} \mathrm{C}, 150{ }^{\circ} \mathrm{C}$, and $180^{\circ} \mathrm{C}$, they had adhesive bondline shear strength values of 15.13 $\mathrm{MPa}$, 11.2 $\mathrm{MPa}, 13.42 \mathrm{MPa}$, and 16.00 $\mathrm{MPa}$, respectively. It appears that compression and heating the samples adversely influenced their adhesive bondline shear strength. It is a fact that a smoother surface will create less interaction between two samples, resulting in lower adhesive bondline shear strength characteristics.

In a previous study, adhesive bondline shear strength of four Japanese species (namely cedar-sugi, cypress-hinoki, arborvitac-hiba, and larch-karamatsu) had lower shear strength properties when they were sanded with finer sand paper as compared to those of sanded with coarser sand paper [21].

In this study, compression and heat also created smoother surface quality of the samples and adversely effected the development of a strong glue line between two pieces. As temperature was increased from $100{ }^{\circ} \mathrm{C}$ to $120^{\circ} \mathrm{C}$ and $150{ }^{\circ} \mathrm{C}$, the reduction in bonding strength of the specimens was determined. They were slightly reduced, as can be observed in Figure 9.

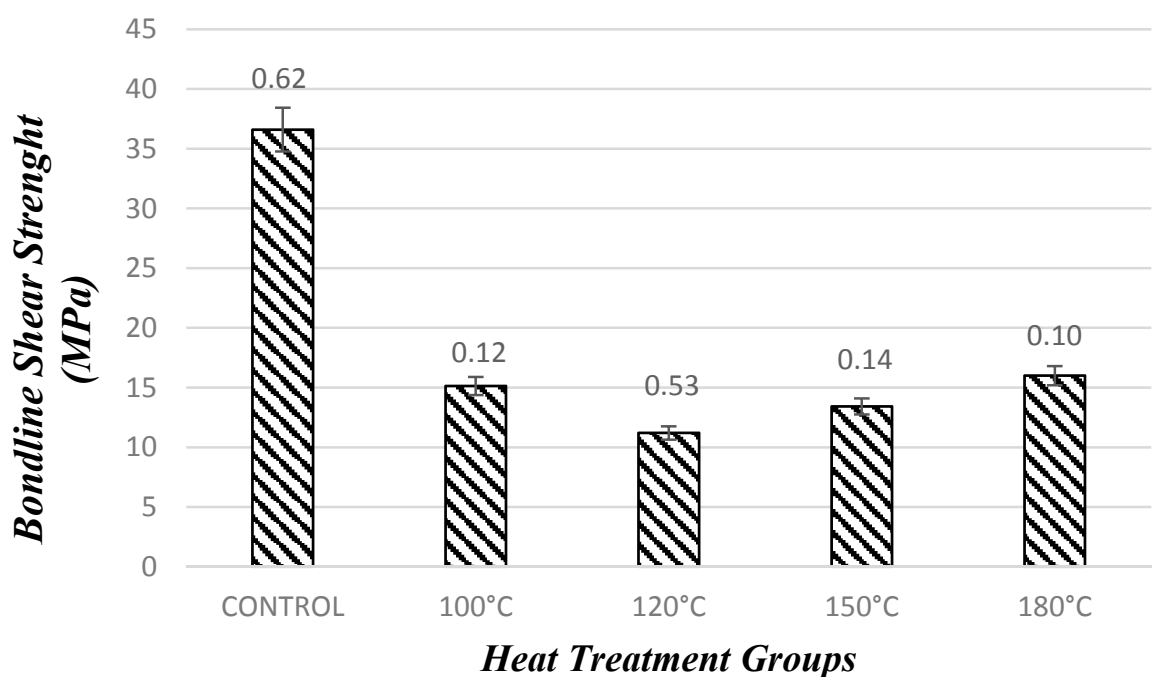

Figure 9. Adhesive bondline shear strength values of the samples after densification process.

It is known that physical and chemical changes in the wood take place during the application of compression with heat. This could possibly be the main reason for such findings. Additionally, the combined effect of heat and compression affects and promotes an inactivated wood surface, resulting in adhesion problems.

\subsubsection{Evaluation of Surface Roughness Tests}

Roughness values taken from the surface of specimens in orientations both across and along the grain improved due to compression. Control species had an average value of $R_{a}$ perpendicular to the grain of $8 \mu \mathrm{m}$, while this value reduced to $4.12 \mu \mathrm{m}, 3.64 \mu \mathrm{m}, 3.56 \mu \mathrm{m}$, and $1.22 \mu \mathrm{m}$ for those samples compressed at temperatures $100^{\circ} \mathrm{C}, 120^{\circ} \mathrm{C}, 150^{\circ} \mathrm{C}$, and $180^{\circ} \mathrm{C}$, respectively, Control species had an average value of $R_{a}$ parallel to the grain of $3.54 \mu \mathrm{m}$, while this value reduced to $1.28 \mu \mathrm{m}$, $1.38 \mu \mathrm{m}, 1.16 \mu \mathrm{m}$, and $1.10 \mu \mathrm{m}$ for samples compressed at temperatures $100{ }^{\circ} \mathrm{C}, 120{ }^{\circ} \mathrm{C}, 150{ }^{\circ} \mathrm{C}$, and $180{ }^{\circ} \mathrm{C}$, respectively.

In a previous work, a $40 \%$ reduction in the surface roughness of poplar veneer was observed when they were compressed in a press [13], and roughness values resulted in significant differences between the measurements taken from the surface of the samples parallel and perpendicular grain orientation. 
In all cases, samples compressed at a temperature of $180^{\circ} \mathrm{C}$ did not show any differentiation. It appears as if compression at a temperature of $180^{\circ} \mathrm{C}$ made the surface layer of the samples substantially soft and plasticized. Figure 10 shows roughness values taken from the surface after the densification process.

Overall, the smoothness of the samples improved with increasing treatment temperature. Significant differences between surface roughness values control and compressed samples as well as values within compressed samples were found based on statistical analysis.

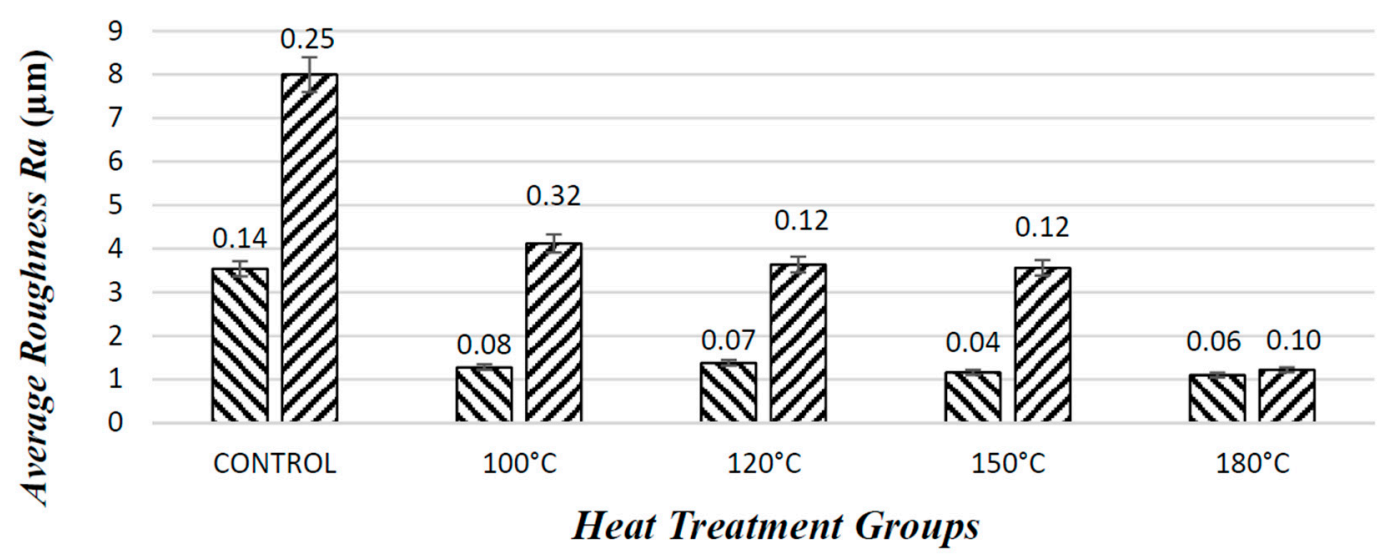

$\boldsymbol{\nabla}$ Surface Roughness Along the Grain

Durface Roughness Across the Grain

Figure 10. Surface roughness values of the samples after densification process.

\subsubsection{Evaluation of Lightness Test}

Densification with heat treatment significantly changed the color values of the samples. The lightness $\left(\mathrm{L}^{*}\right)$ value was measured as higher (74.39) for control samples. After densification with heat treatment, the $L^{*}$ value of samples significantly decreased depending on the increase of temperature levels. When compared to control samples, the $\mathrm{L}^{*}$ value decreased to 53.60, 44.17, 35.99 , and 29.32 for samples compressed at temperature levels of $100^{\circ} \mathrm{C} 120^{\circ} \mathrm{C}, 150{ }^{\circ} \mathrm{C}$, and $180^{\circ} \mathrm{C}$, respectively, as depicted in Figure 11.

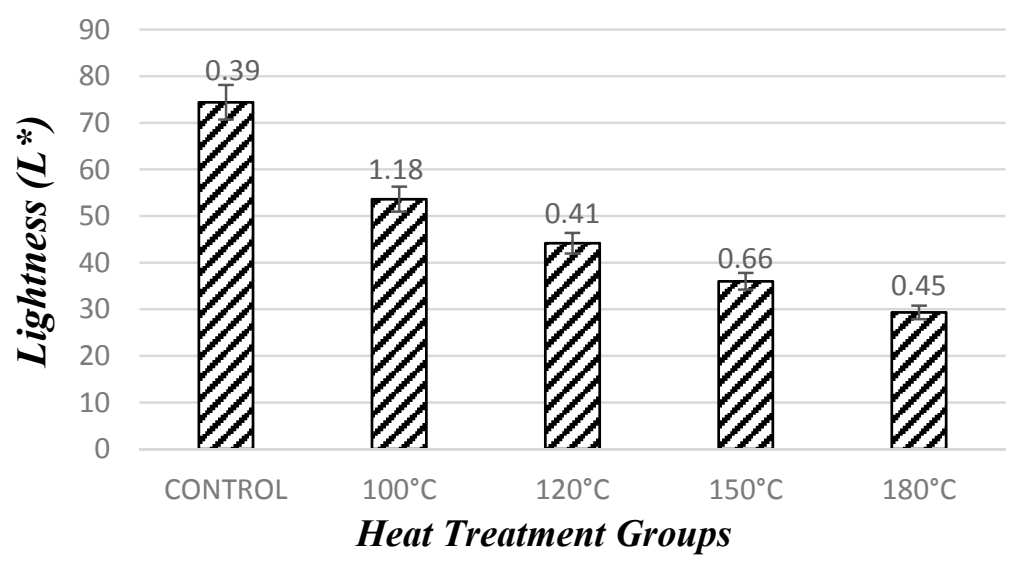

Figure 11. Color values of the samples after densification process.

In previous studies, it has been expressed that the color of the wood darkened more with the increasing temperature and duration [20,22-25]. Overall lightness of the samples decreased with treatment temperature. Significant differences between lightness values of control and compressed samples as well as values within compressed samples were found based on statistical analysis. 


\subsubsection{Evaluation of Hardness Tests}

Figure 12 shows hardness values of the specimens in both grain orientations. The highest value was $1262 \mathrm{lbs}$ across the grain orientation of the specimens exposed to a temperature of $150{ }^{\circ} \mathrm{C}$. As press temperature increased, overall hardness characteristics of the samples also gradually increased.

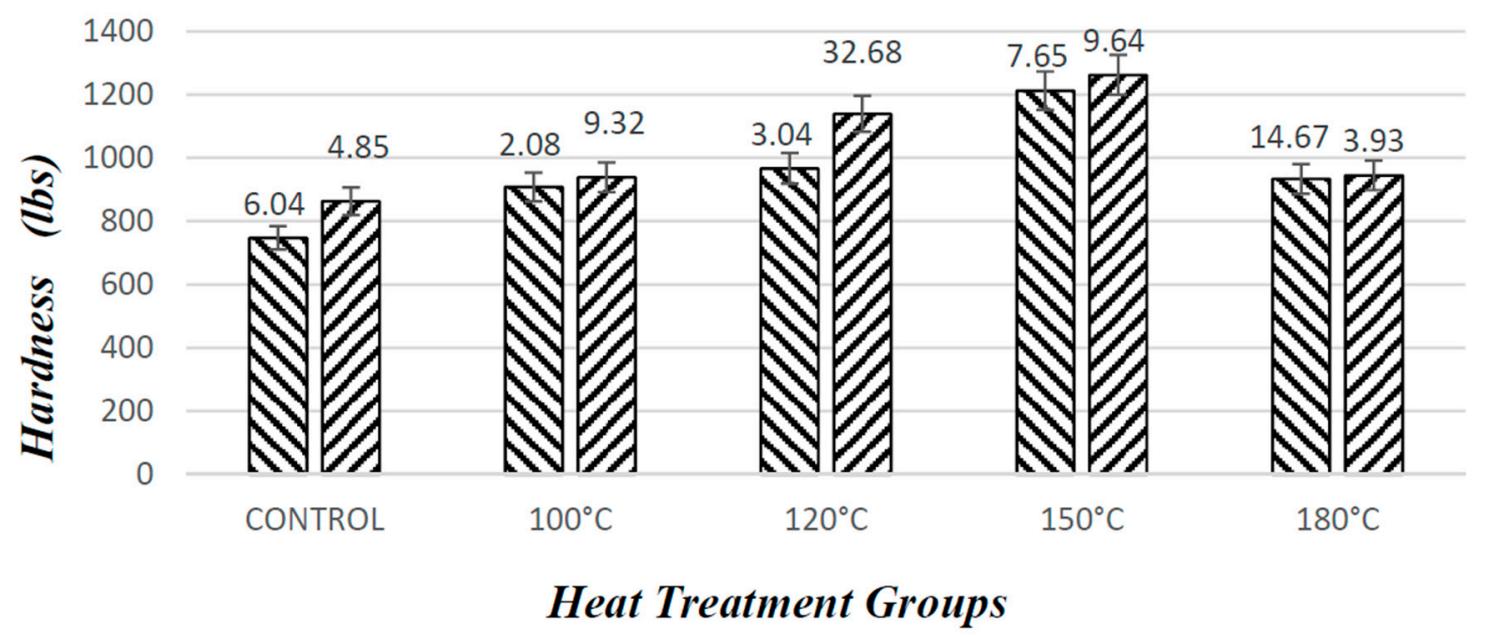

\section{$\nabla$ Along the Grain $\boldsymbol{\nabla}$ Across the Grain}

Figure 12. Hardness values of the samples after the densification process.

Including control samples, all of the specimens had higher hardness taken from perpendicular to the grain orientation than that taken parallel to the grain orientation, which is the expected result due to the anatomical structure of wood material. It seems that $150{ }^{\circ} \mathrm{C}$ temperature was the threshold point for hardness values of the samples. Beyond this point, when samples were compressed at a temperature of $180{ }^{\circ} \mathrm{C}$, their hardness values reduced $23 \%$ parallel to the grain orientation and $25 \%$ perpendicular to the grain orientation, as can be observed in Figure 12. It is a known fact that high temperature close to $200{ }^{\circ} \mathrm{C}$ creates a certain amount of degradation of the chemical structure, and this is reflected in the adverse influence on mechanical properties.

\section{Conclusions}

This study investigated the influence of thermomechanical densification on surface quality, adhesive bondline shear strength, hardness, and color changes of densified eastern redcedar. Based on the findings in this work, overall surface roughness characteristics of samples exposed to different temperatures were enhanced as a result of densification. This positive effect was more pronounced in the care of the sample exposed to a temperature of $120^{\circ} \mathrm{C}$. Data found in this work are useful for more efficient use of wood as a value-added product from eastern redcedar which is a lesser utilized species. In further studies, some of the other mechanical properties such as bending and compression strength in addition to dimensional stability of the samples would be interesting to investigate to have a better understanding of the behavior of densified eastern redcedar.

Acknowledgments: This research was carried out during the visit of principal author to Oklahoma State University in the USA founded by TUBITAK Turkey.

Author Contributions: O.U. and S.H. conceived and designed the experiments; O.U. performed the experiments; S.H. analyzed the data; O.U. contributed reagents/materials/analysis tools; O.U. wrote the paper.

Conflicts of Interest: The authors declare no conflict of interest. 


\section{References}

1. Inoue, M.; Norimoto, M.; Tanahashmi, M.; Rowell, R.M. Steam or heat fixation of compressed wood. Wood Fiber Sci. 1993, 25, 224-235.

2. Diouf, P.N.; Stevanovic, T.; Cloutier, A.; Fang, C.H.; Blanchet, P.; Koubaa, A.; Mariotti, N. Effects of thermo-hygro-mechanical densification on the surface characteristics of trembling aspen and hybrid poplar wood veneers. Appl. Surf. Sci. 2011, 257, 3558-3564. [CrossRef]

3. Kollmann, F.P.; Kuenzi, E.W.; Stamm, A.J. Principles of Wood Science and Technology; Vol. II Wood Based Materials; Springer: New York, NY, USA; Heidelberg/Berlin, Germany, 1975; pp. 139-149.

4. Kultikova, E.V. Structure and Properties Relationships of Densified Wood. Master's Thesis, Virginia Polytechnic Institute and State University, Blacksburg, VA, USA, 1999; p. 136.

5. Kutnar, A.; Sernek, M. Densification of wood. Zbornik Gozdarstva Lesarstva 2007, 82, 53-62.

6. Ulker, O.; Imırzı, O.; Burdurlu, E. The effect of densification temperature on some physical and mechanical properties of Scots pine. BioResources 2012, 7, 5581-5592. [CrossRef]

7. Morsing, N. Densification of Wood-The Influence of Hygrothermal Treatment on Compression of Beech Perpendicular to the Grain; Department of Structural Engineering and Materials, Technical University of Denmark: Lyngby, Denmark, 2000; Volume 79, pp. 138-177.

8. Dwianto, W.; Morooka, T.; Norimoto, M.; Kitajima, T. Stress relaxation of sugi (Cryptomeria japonica D. Don) wood in radial compression under high temperature steam. Holzforschung 1999, 53, 541-546. [CrossRef]

9. İmirzi, H.O.; Ülker, O.; Burdurlu, E. Effect of densification temperature and some surfacing techniques on the surface roughness of densified Scots pine. Bioresources 2013, 9, 191-209. [CrossRef]

10. Blomberg, J.; Persson, B.; Blomberg, A. Effects of semi-isostatic densification of wood on the variation in strength properties with density. Wood Sci. Technol. 2005, 39, 339-350. [CrossRef]

11. Bekhta, P.; Hiziroglu, S.; Shepelyuk, O. Properties of plywood manufactured from compressed veneer as building material. Mater. Des. 2009, 30, 947-953. [CrossRef]

12. Candan, Z.; Hiziroglu, S.; McDonald, A.G. Surface quality of thermally compressed Douglas fir veneer. Mater. Des. 2010, 31, 3574-3577. [CrossRef]

13. Aydin, I.; Colakoglu, G. Effects of surface inactivation, high temperature drying and preservative treatment on surface roughness and color of alder and beech wood. Appl. Surf. Sci. 2005, 252, 430-440. [CrossRef]

14. Dilik, T.; Hiziroglu, S. Bonding strength of heat treated compressed Eastern redcedar wood. Mater. Des. 2012, 42, 317-320. [CrossRef]

15. Seborg, R.M.; Millett, M.A.; Stamm, A.J. Heat-Stabilized Compressed Wood (Staypak); US Dept. of Agriculture, Forest Service, Forest Products Laboratory: Madison, WI, USA, 1956; pp. 1-21.

16. Fu, Q.; Cloutier, A.; Laghdir, A. Optimization of the Thermo-Hygromechanical (THM) Process for Sugar Maple Wood Densification. BioResources 2016, 11, 8844-8859. [CrossRef]

17. Kasemsiri, P.; Hiziroglu, S.; Rimdusit, S. Characterization of heat treated eastern redcedar (Juniperus virginiana L.). J. Mater. Process. Technol. 2012, 212, 1324-1330. [CrossRef]

18. Mummery, L. Surface Texture Analysis: The Handbook; Hommelwerke: Muhlhausen, Germany, 1993.

19. Priadi, T.; Hiziroglu, S. Characterization of heat treated wood species. Mater. Des. 2013, 49, 575-582. [CrossRef]

20. Bekhta, P.; Niemz, P. Effect of high temperature on the change in color, dimensional stability and mechanical properties of spruce wood. Holzforschung 2003, 57, 539-546. [CrossRef]

21. Shida, S.; Hiziroglu, S. Evaluation of shear strength of Japanese wood species as a function of surface roughness. For. Prod. J. 2010, 60, 400-404. [CrossRef]

22. Militz, H. Thermal Treatment of Wood: European Processes and Their Background; IRG/WP: Stockholm, Sweden, 2002.

23. Mitsui, K.; Murata, A.; Kohara, M.; Tsuchikawa, S. Colour modification of wood by light-irradiation and heat treatment. In Proceedings of the First European Conference on Wood Modification, Ghent, Belgium, 3-4 April 2003. 
24. Akgül, M.; Korkut, S. The effect of heat treatment on some chemical properties and colour in Scots pine and Uludağ fir wood. Afr. J. Biotechnol. 2012, 7, 2854-2859.

25. Toker, H.; Baysal, E.; Kotekli, M.; Turkoglu, T.T.; Kart, S.; Sen, T.F.; Peker, T.H. Surface characteristics of oriental beech and scots pine woods heat-treated above $200{ }^{\circ} \mathrm{C}$. Wood Res. 2016, 61, 43-54.

(C) 2017 by the authors. Licensee MDPI, Basel, Switzerland. This article is an open access article distributed under the terms and conditions of the Creative Commons Attribution (CC BY) license (http:/ / creativecommons.org/licenses/by/4.0/). 